\title{
RNA/DNA ratios and DNA concentrations as indicators of growth rate and biomass in planktonic marine organisms
}

\author{
Quay Dortch", Todd L. Roberts, J. R. Clayton, Jr.** and S. I. Ahmed \\ School of Oceanography WB-10, University of Washington, Seattle, Washington 98195, USA
}

\begin{abstract}
RNA and DNA concentrations were measured by a modification of the ethidium bromide method in batch cultures of marine phytoplankton and in natural plankton populations (1 to $333 \mu \mathrm{m}$ ) from Dabob Bay, Washington State, USA, in spring and summer of 1981. In the cultures the DNA/C ratio remained nearly constant during all phases of growth and growth rate was linearly related to the RNA/DNA ratio. The DNA/C ratio and the relationship between growth rate and RNA/DNA ratio for cultures was used to estimate the amount of living biomass and the growth rates for plankton populations of Dabob Bay. The amount of living carbon was never $<57 \%$ of the total particulate carbon and average growth rates ranged from $<0.3$ divisions $\mathrm{d}^{-1}$ to $>4$ divisions $\mathrm{d}^{-1}$. Some of the potential problems with such calculations, for example, occurrence of detrital DNA, variability in the DNA/C ratio for different groups of organisms, and differences in the relationship between growth rate and RNA/DNA ratio, are discussed. However, these problems may not be major obstacles to using DNA concentrations and RNA/DNA ratios for answering major questions in biological oceanography.
\end{abstract}

\section{INTRODUCTION}

RNA and DNA are compounds found in all living organisms. DNA is the genetic template; its cellular concentrations may be related to cell size and be relatively insensitive to changes in environmental conditions. In contrast, RNA is involved in protein synthesis, which is required for growth. Its cellular concentration is highly dependent on the growth rate, which is determined in part by environmental conditions. As a consequence, DNA concentrations may be a good measure of living biomass and RNA/DNA ratios may be a good indicator of growth rates of planktonic marine organisms. Measuring biomass and growth rates of planktonic organisms is a difficult analytical problem, but such knowledge is essential for answering fundamental questions in biological oceanography.

Early studies of RNA and DNA in non-marine bacteria showed that the RNA/DNA ratio was linearly related to growth rate whereas the DNA/dry weight ratio was almost constant (Caldwell et al., 1950; Jeener, 1953; Neidhardt and Magasanik, 1960; Kjeld-

- Current address: Bigelow Laboratory for Ocean Sciences, Mckown Point, West Boothbay Harbor, Maine 04575, USA

- Current address: School of Fisheries WH-10, University of Washington, Seattle, Washington 98195, USA gaard and Kurland, 1963; Rosset et al., 1966; Leick, 1968; Dennis and Bremer, 1974; Brunschede et al., $1977)$. These results led Sutcliffe $(1965,1969)$ to propose that the RNA content of marine invertebrates could be used as an indicator of growth rates, and HolmHansen (Holm-Hansen et al., 1968; Holm-Hansen, 1969) to suggest that the concentration of DNA would be a good measure of living carbon in phytoplankton. Although the RNA/DNA ratio or the RNA content has since been used successfully as a measure of growth rate in a variety of larger marine animals (Bulow, 1970; Dagg and Littlepage, 1972; Haines, 1973; Båmstedt and Skjoldal, 1976; Pease, 1976; Skjoldal and Båmstedt, 1976; Buckley, 1979; Båmstedt and Skjoldal, 1980), measurements of RNA/DNA or DNA concentrations have not been utilized extensively for investigating growth rates or biomass of planktonic marine organisms.

Several reasons can be cited for the failure to utilize these potentially useful measurements: (1) Methods for measuring RNA and DNA, which are chemically quite similar, require lengthy extractions to separate the two and remove interfering substances and are not very sensitive. (2) Holm-Hansen et al. (1968) hypothesized from indirect evidence that the presence of detrital DNA in seawater prevented the use of DNA as a measure of living carbon. (3) Some variation in the 
relationship of the RNA content or the RNA/DNA ratio with growth rate has been observed in the studies of larger marine animals mentioned above, although the variation may not be great enough (Båmstedt and Skjoldal, 1980) to preclude the use of RNA/DNA ratios to estimate growth rates. Furthermore, the early studies with bacteria suggest that this may be less of a problem with smaller organisms, but there are no data for marine bacteria, phytoplankton, or small zooplankton to evaluate the extent of the difficulty.

The first problem has been solved with the development of a new method for quickly and easily measuring RNA and DNA on the same extract (Prasad et al., 1972). A sample of seawater or culture is filtered, ground, and centrifuged. To an aliquot of the supernatant is added ethidium bromide, a dye which reacts with both RNA and DNA to produce a highly fluorescent compound. After the total fluorescence is measured, an enzyme, RNAse, is added which selectively destroys RNA. The fluorescence due to DNA is read directly and that due to RNA is calculated from the difference between the total and DNA fluorescence. Concentrations are then computed by the use of appropriate standard curves.

We report here our preliminary studies measuring RNA and DNA in cultures of marine phytoplankton and in the plankton obtained from Dabob Bay, a small fjord-like bay in Washington State, throughout the spring and summer of 1981 . The purpose of undertaking the culture studies was (1) to determine whether RNA and DNA comprise a sizeable portion of the cellular nitrogen and how their concentrations vary as a result of nitrogen deficiency; (2) to investigate the relationship between RNA/DNA and growth rate; and (3) to measure the ratio of DNA/C, needed to estimate living carbon from DNA concentrations. The field studies were designed to determine if it is feasible to make measurements of RNA and DNA on natural plankton populations and if the RNA/DNA ratios and DNA concentrations can provide useful information about biomass and growth rates. Dabob Bay was chosen because its seasonal cycle of primary productivity and hydrography make it a good model of the open temperate ocean (Shuman, 1978).

\section{MATERIALS AND METHODS}

\section{Culture experiments}

The 2 species used in these studies were Amphidinum carterae Hulburt (University of Washington, Department of Oceanography clone no. AC-AM-10) and Thalassiosira nordenskioldii Cleve (Northeast Pacific Culture Collection, University of British Co- lumbia clone no. 252). They were grown on artificial seawater (Kester et al., 1967) with vitamins and trace metals added at f/2 (Guillard and Ryther, 1962) and with phosphate $(>50 \mu \mathrm{m})$ and silicate $(>100 \mu \mathrm{m}) \mathrm{kept}$ at high, non-limiting concentrations. One culture of each species was started with ca. $100 \mu \mathrm{M}$ ammonium, another one with $100 \mu \mathrm{M}$ nitrate. When the nitrogen source was depleted, each culture was diluted with artificial seawater, made up with all nutrients added except nitrogen (nitrogen-free seawater), to prevent light limitation or limitation by another nutrient besides nitrogen. Continuous light was provided by Very High Output (VHO) daylight fluorescent bulbs covered by a blue Plexiglas filter (Rohm and Haas No. 2069). The light intensity was between 125 and $350 \mu \mathrm{E} \mathrm{m}^{-2} \mathrm{~s}^{-1}$ and the spectral distribution simulated $5 \mathrm{~m}$ underwater light under sunny conditions for Jerlov type 3 coastai water (Davis, 1972). The temperature was maintained at $17^{\circ} \mathrm{C}$ by a circulating water bath. Samples were collected for nutrient analyses, cell counts and average cell volumes, total cellular nitrogen and carbon concentrations, and RNA and DNA concentrations twice a day during exponential growth and once a day during stationary phase.

\section{Field studies}

Five cruises were made to Dabob Bay during spring and summer of 1981 on the R. V. 'Onar'. Samples were always collected at the same station $\left(47^{\circ} 48^{\prime} 59^{\prime \prime} \mathrm{N}\right.$ and $\left.122^{\circ} 48^{\prime} 25^{\prime \prime} \mathrm{W}\right)$ with a large volume $(601)$, stainless steel sampler (Young et al., 1969). All water samples were then passed through $333 \mu \mathrm{m}$ Nitex netting to remove larger zooplankton.

On 4 of 5 cruises (see Table 1 for dates), the station was occupied for longer than $24 \mathrm{~h}$ and samples were collected from 2 depths at 4 to $6 \mathrm{~h}$ intervals. For the remaining cruise (May 4 to 5), the sampling period was reduced to $12 \mathrm{~h}$ due to a problem with the research vessel. The 2 depths were chosen to correspond with what would become by late spring a nitrogen depleted surface layer and a deeper layer with high nitrogen concentrations (Christensen, 1974; Shuman, 1978). The primary purpose for occupying this station for longer than $24 \mathrm{~h}$ was to conduct studies of diel periodicity in phytoplankton nitrogen assimilation rates (Clayton et al., in prep.). For the purposes of this paper the concentrations obtained for all the pertinent measurements were averaged for each cruise and depth in order to show seasonal trends. On 3 cruises (see Fig. 6 for dates), after sampling the 2 depths for 24 h or more, water samples from 5 depths above $25 \mathrm{~m}$ were collected and processed as rapidly as possible in order to obtain more detailed depth profiles of the same chemical and biological parameters 


\section{Sampling and analyses}

Samples were filtered onto precombusted $\left(350^{\circ} \mathrm{C}, 24\right.$ h) Whatman GF/C (laboratory experiments, nominal pore size $1.2 \mu \mathrm{m}$ ) or $934-\mathrm{AH}$ (field studies, nominal pore size approximately $1 \mu \mathrm{m}$ ) glass fiber filters. A sizeable fraction of the total particulate DNA, and presumably RNA, has been found to be associated with bacteria $<1 \mu \mathrm{m}$ size (Paul and Carlson, pers. comm.). Thus, with the filters used in this study the particulate matter collected probably represents phytoplankton and zooplankton between 1 and $333 \mu \mathrm{m}$ in size. The vacuum differential for filtration was kept low $<10 \mathrm{~cm}$ $\mathrm{Hg}$ ) because of earlier results showing the cell contents were lost at greater differential vacuums (Dortch, unpubl.). Depending on the amount of biomass present, between 25 and $100 \mathrm{ml}$ were filtered for all analyses in the laboratory experiments and between 1 and $3 \mathrm{l}$ in the field studies. Samples for RNA, DNA, and chlorophyll analyses were stored in liquid $\mathrm{N}_{2}$ $\left(-196^{\circ} \mathrm{C}\right)$ for field samples and at $-15^{\circ} \mathrm{C}$ for laboratory experiment samples. Filters for total nitrogen and carbon analyses were frozen at $-15^{\circ} \mathrm{C}$ over desiccant until further analysis.

RNA and DNA were extracted from the filtered samples by grinding the sample for $2 \mathrm{~min}$ in distilled, deionized water chilled in an ice water bath. This simple method of extraction was chosen after investigating both grinding and sonication with several buffers, none of which gave more complete extraction. The number of possible extraction media is limited, because it must not inhibit the later degradation step with RNAse. Earlier studies have shown that distilled, deionized water is also the most effective means of extracting internal, inorganic nitrogen pools from phytoplankton, probably as a result of osmotic shock (Thoresen et al., 1982). After grinding, the samples were centrifuged at high speed in a desk top centrifuge and the supernatants stored on ice until analysed. The procedure was similar to that of Prasad et al. (1972) except that ethidium bromide was made up in Tris- NaCl buffer since the samples were not extracted in buffer. Fluorescence was measured using a Turner 430 spectrofluorometer. Biochemicals - e. g. ethidium bromide, Type III RNA, Type I DNA and Type IIIA RNAse - were obtained from Sigma Chemical Company.

Most RNA/DNA and DNA/C ratios are expressed on a weight basis. However, the percent values of total nitrogen which RNA and DNA represented were also of interest. The base composition of algal DNA and RNA is highly variable (Green, 1974), so in order to calculate the nitrogen content of algal RNA and DNA each was assumed to contain equal amounts of its 4 principal nucleotides and the nitrogen content of those was averaged. Thus, DNA is approximately $16.84 \%$ nitrogen by weight and RNA $16.12 \%$.

Chlorophyll a was measured spectrophotometrically according to Jeffrey and Humphrey (1975). Nitrate, nitrite, and ammonium concentrations were measured on an AutoAnalyser ${ }^{(B)}$ using the methods in Friederich and Whitledge (1972). Samples were filtered immediately after collection. Those from the laboratory were run fresh, whereas those collected in the field were frozen for later analysis. Total nitrogen and carbon analyses were made with a Perkin-Elmer model 240 Elemental Analyser. Cell counts and average cell volumes were measured microscopically on samples preserved with Lugol's solution, although unpreserved samples were examined daily during the culture experiments. Growth rates were calculated from changes in total cell volume (liter cell volume/liter culture volume $=$ \# cell/liter $\times$ average cell volume) over each time interval between measurements. Total cell volume was chosen instead of cell number because the cell size changed over time in each experiment.

\section{RESULTS}

\section{Laboratory experiments with phytoplankton cultures}

In 3 out of 4 cultures, growth continued for some time after the external nitrogen source was depleted (Fig. 1). Since the total cellular nitrogen content decreased until cell growth ceased, presumably growth continued at the expense of internally stored nitrogen. As expected, one of the internal nitrogen compounds which was utilized was RNA, although, since RNA is required for protein synthesis during growth, its cellular concentration did not decrease as rapidly as the total cellular nitrogen. In contrast, the DNA content of the cells, and, thus, the DNA/C ratio, remained constant throughout the exponential and stationary phase of the cultures. If the DNA concentration in the culture had been plotted in Fig. 1A it would parallel the growth curve. Consequently, by the time stationary phase was reached at the end of the experiments, an average for the 3 cultures of $80 \pm 13.8 \%$ (mean $\pm \mathrm{SE}$ ) of the DNA-N remained in the cells, $26 \pm 5.9 \%$ of the RNA-N and $33 \pm 5.4 \%$ of the total nitrogen. Clearly, cellular DNA is conserved although total nitrogen and RNA decrease as a result of nitrogen deficiency.

For the remaining culture (Fig. 2), growth ceased before the external nitrate was utilized. Total cellular nitrogen content did not decrease, indicating that something other than the supply of nitrogen limited growth. However, RNA content did decrease as cell growth slowed and DNA content remained almost con- 


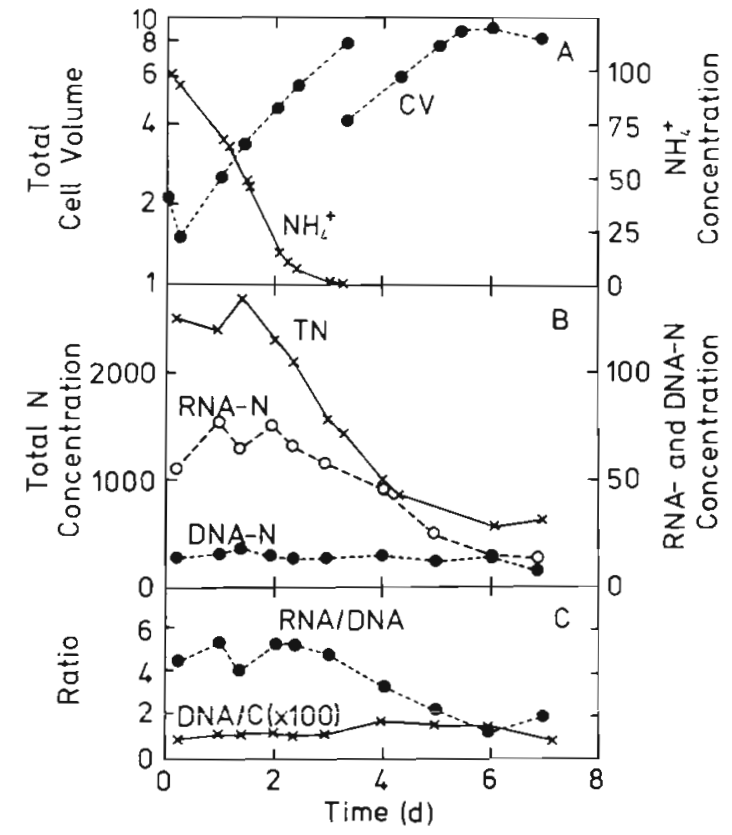

Fig. 1. Cellular content of RNA-N, DNA-N, and total N (mmol $\mathrm{N}^{-1}$ cell volume) and RNA/DNA and DNA/C ratios (by wt) in a batch culture of Thalassiosira nordenskioldii growing initially on $\mathrm{NH}_{4}^{+}(u \mathrm{M})$. In (A) growth expressed in terms of total cell volume (liter cell volume/liter culture volume, $\left.\times 10^{-5}\right)$; break in growth curve was caused by diluting the culture (see 'MATERIALS AND METHODS')

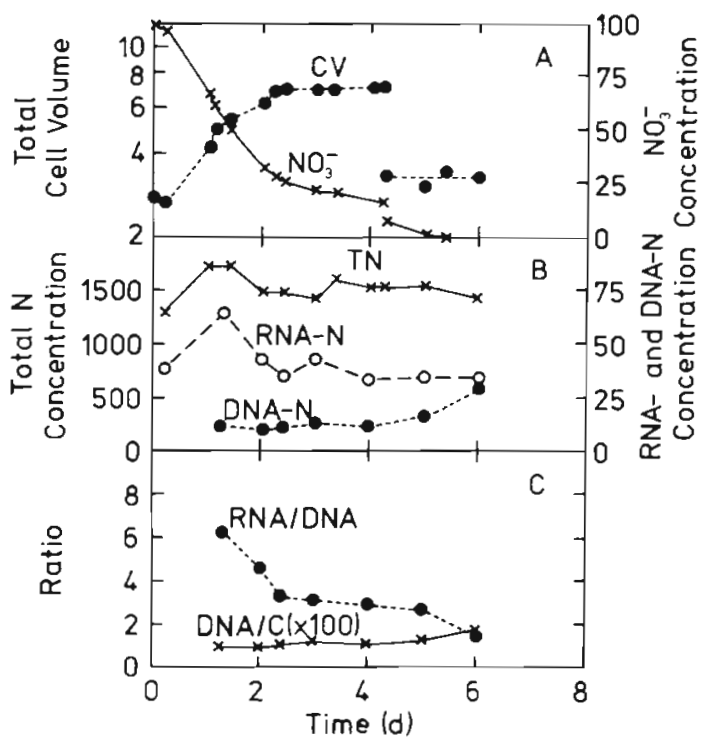

Fig. 2. Changes in cellular content of RNA-N, DNA-N and total $\mathrm{N}$ (mmol $\mathrm{N}^{-i}$ cell volume) and in RNA/DNA and DNA/ C ratios (by wt) in a batch culture of Thalassiosira norden-

skioldii growing initially on $\mathrm{NO}_{3}^{-}(\mu \mathrm{M})$. (A) as in Fig. 1

stant. Because of the high initial nutrient concentrations, including trace metals, vitamins, silicate, and phosphate, it is unlikely that any nutrient limited growth. However, from the second day of the experi- ment, numerous empty frustules were apparent, suggesting the culture was unhealthy.

Since the cellular content of DNA remained constant while that of RNA decreased, the ratio of RNA/DNA decreased as a result of nitrogen deficiency and/or cessation of growth (Figs. $1 \mathrm{C}$ and $2 \mathrm{C}$ ). In fact there appears to be a linear relationship between growth rate and RNA/DNA ratio for the 3 nitrogen-limited cultures (Fig. 3), which can be described by

$\mu=0.255$ RNA/DNA $-0.287, \mathrm{r}^{2}=0.725, \mathrm{n}=26$

(geometric mean or model II linear regression; Ricker, 1973; Laws and Archie, 1981), where $\mu=$ growth rate in div/da; RNA/DNA = ratio by weight; all data during lag phase are excluded. Considering that no attempt was made to control growth rates, that growth was at times 'unbalanced' (Eppley, 1981), and that

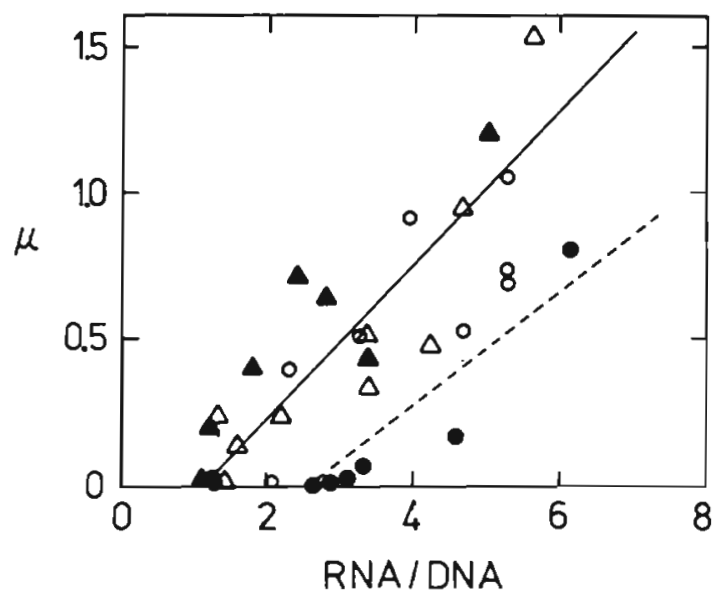

Fig. 3. Growth rate $\left(\mu_{i} \operatorname{div} d^{-1}\right)$ as a function of RNA/DNA ratio (by wt): $O$ Thalassiosira nordenskioldii $\mathrm{NH}_{4}^{+} ; \bullet T$. nordenskioldii, $\mathrm{NO}_{3}^{-} ; \triangle$ Amphidinium carterae, $\mathrm{NH}_{4}^{+} ; \Delta A$. carterae, $\mathrm{NO}_{3}^{-}$. Solid line: Equation (1) for the 3 nitrogen-deficient cultures; broken line: Equation (2) for $T$. nordenskioldii. $\mathrm{NO}_{3}^{-}$

calculating growth rates between pairs of points should result in enormously variable growth rates, the correlation coefficient is remarkably high. The data for the non-nutrient limited culture falls below that of the other 3 cultures (Fig. 3), and can be described by

$\mu=0.156$ RNA/DNA $-0.525, \mathrm{r}^{2}=0.768, \mathrm{n}=7$

Its slope is not significantly different from that of the other 3, but the $y$-intercept is obviously different. Thus the RNA/DNA ratio at which growth ceases differs for this culture.

As expected from the nearly constant DNA content and the constant DNA/C ratio, the DNA concentration $\left(\mu \mathrm{gl}^{-1}\right.$ of culture) is linearly related to the carbon concentration ( $\mu \mathrm{gl}^{-1}$ of culture) for all 4 cultures (Fig. 4). 
DNA $=0.0154 \mathrm{C}-23.94, \mathrm{r}^{2}=0.698, \mathrm{n}=46$

Due to the large $x$-intercept, indicating the presence of detrital carbon in the cultures, the slope of the DNA vs Cregression is the best means of computing the DNA/ C ratio, which is $1.54 \%$.

RNA and DNA together rarely comprise more than $5 \%$ of the total cellular nitrogen in the 2 species examined. The average nucleic acid content of Amphidinium carterae $(4.62 \pm 0.837 \% ; \mathrm{n}=20$; mean $\pm 1 \mathrm{SD}$ ) was significantly greater (one tailed t-test; $\mathrm{p}<0.01$ ) than that of Thalassiosira nordenskioldii $(3.76 \pm 0.727 \% ; n=16)$. However, during the course of each experiment, the percentage of the total nitrogen in RNA tended to decrease, while that in DNA increased.

\section{Field studies}

Seasonal variation of RNA-N and DNA-N concentrations and RNA/DNA ratio in the surface layer $(<6 \mathrm{~m}$ of Dabob Bay, as well as measurement of total (particulate) nitrogen and carbon concentrations, chlorophyll a concentrations, and ambient nitrate concentrations, are given in Fig. 5. Spring phytoplankton bloom occurred in early April (Fig. 5B), after which nitrate (Fig. 5B) became depleted in the surface layer and ammonium reached undetectable levels. RNA-N concentrations were maximal during the phytoplankton bloom, although DNA-N concentrations were highest during the next cruise. As a consequence, the highest RNA DNA ratios were observed at the time of the bloom.

Depth profiles (Fig.6) show the same seasonal trend observed for the surface layer. However, as incident radiation increased and nitrogen became depleted in the surface layer, most of the biomass was found below the surface. Chlorophyll $a$, particulate nitrogen and organic carbon all showed maxima that increased in depth as the season progressed. The DNA-N profile did not necessarily parallel that of the other biomass measures, often showing a maximum concentration near the surface. However, the RNA/DNA ratio was always maximal near the nutricline and the chlorophyll maximum.

Early in the season RNA-N plus DNA-N comprised more than $10 \%$ of the total (particulate) nitrogen (Table 1). This was much higher than the $5 \%$ observed in the culture studies. By July the RNA-N plus DNA-N represented on the average only $5 \%$ of the total nitrogen, with some values as low as $2.6 \%$.

Seasonal changes in mean growth rates were estimated from the surface and deep RNA/DNA ratios, using Equation (1) (Table 1). They range from a low value of $0.36 \mathrm{div} \mathrm{d}^{-1}$ to a high of $2.1 \mathrm{div} \mathrm{d}^{-1}$ observed during the spring bloom. However, the highest growth

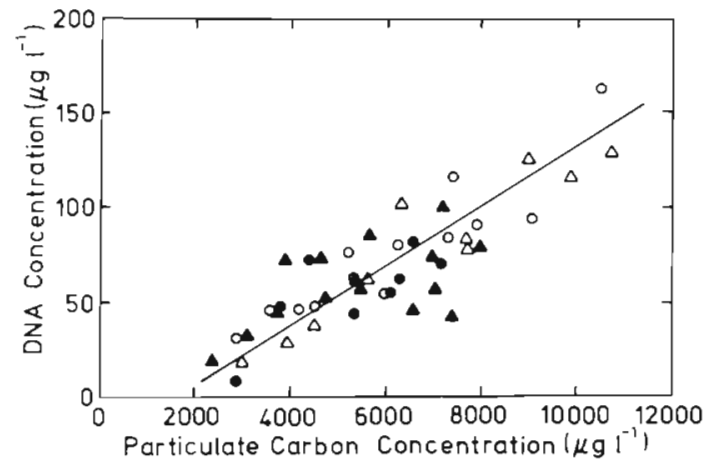

Fig. 4. DNA concentration as a function of total carbon concentration. Symbols as in Fig. 3. Line represents Equation (3)

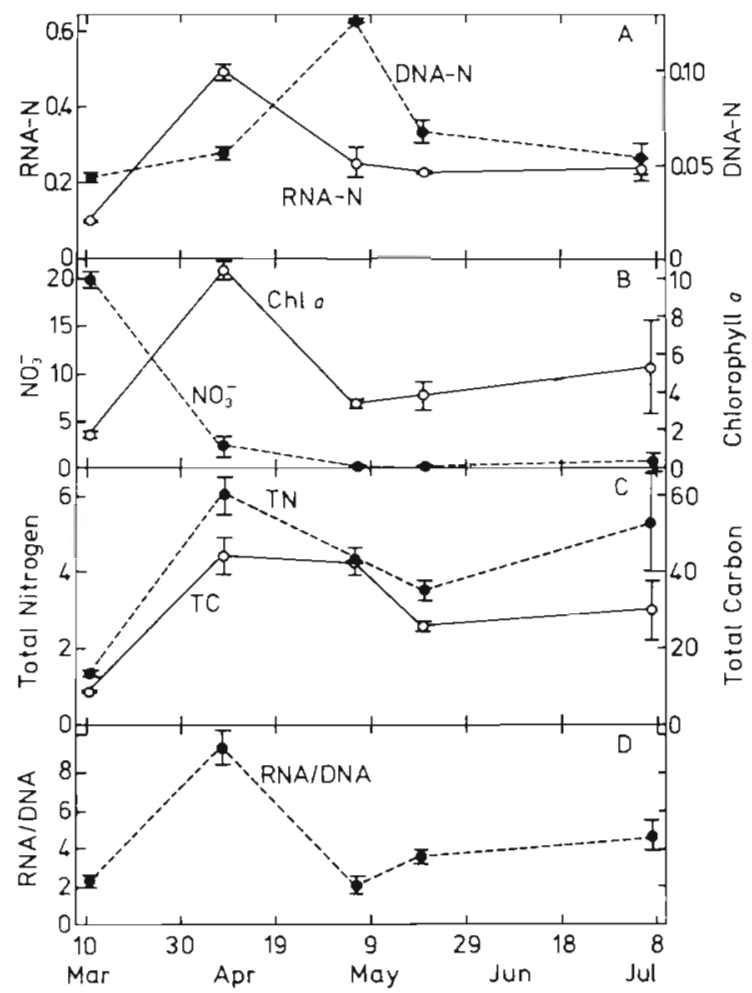

Fig. 5. Seasonal variation of DNA-N and RNA-N concentrations ( $\mu \mathrm{mol} \mathrm{N} \mathrm{l}^{-1}$ seawater), chlorophyll a concentrations ( $\mu \mathrm{g}$ $\left.1^{-1}\right), N_{3}^{-}$concentrations $(\mu \mathrm{M})$, total (particulate) nitrogen and carbon concentrations ( $\mu \mathrm{mol} \mathrm{N}$ or $\mathrm{Cl}^{-1}$ seawater), and RNA/ DNA ratio (by wt) in the surface layer of Dabob Bay (see Table 1 for exact depths). Error bars: one standard error above and below mean, calculated over 12 to $36 \mathrm{~h}$ as described in 'Materials and Methods

rate, $4.4 \operatorname{div~}^{-1}$, was calculated for the chlorophyll maximum observed at $15 \mathrm{~m}$ depth on July 8 (Fig. 6).

When the DNA concentration was plotted as a function of the total particulate carbon concentration (Fig. 7), no significant relationship was obtained for all the data. This is probably not surprising since there is no reason to expect the percentage of living carbon to be constant, even for one cruise, much less over the 


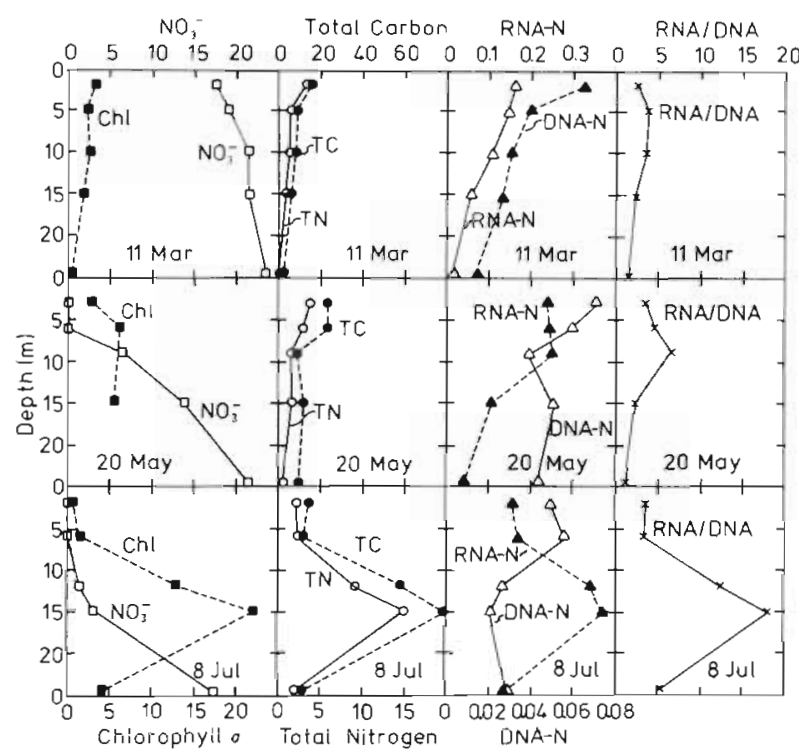

Fig. 6. Depth profiles of DNA-N, RNA-N, chlorophyll $a$, nitrate, and total (particulate) nitrogen, as well as organic carbon concentrations and RNA/DNA ratios during 3 cruises to Dabob Bay. Units as in Fig. 5

course of the entire season. Thus, it was not possible to assess the significance of detrital DNA from the intercept of regressions of DNA and particulate organic carbon concentrations. To determine the concentration of living carbon, the DNA/C ratios obtained from the phytoplankton culture studies, $1.54 \%$, were used. Generally, the calculated concentration of living carbon exceeded the total particulate carbon (Table 1), except when chlorophyll concentrations were high. Then values more similar to what is expected were obtained. The factor of $1.54 \%$ is clearly only applicable when phytoplankton constitute a major portion of the biomass.

Table 1. Mean \% nitrogen, \% living carbon, and growth rate ( $\mu$ ) calculated over 12 to $36 \mathrm{~h}$ for deep and surface layers of Dabob Bay (see MATERIALS AND METHODS)

\begin{tabular}{|c|c|c|c|c|c|}
\hline \multirow[t]{2}{*}{ Date } & \multirow{2}{*}{$\begin{array}{l}\text { Depth } \\
\text { (m) }\end{array}$} & \multicolumn{2}{|c|}{$\% \mathrm{~N}^{1}$} & \multirow{2}{*}{$\begin{array}{l}\% \text { living }^{2} \\
\text { carbon }\end{array}$} & \multirow[t]{2}{*}{$\mu^{3}$} \\
\hline & & RNA & DNA & & \\
\hline \multirow{2}{*}{ Mar 10-11 } & 5 & 7.73 & 3.23 & 219 & 0.35 \\
\hline & 15 & 5.98 & 2.99 & 196 & 0.26 \\
\hline \multirow{2}{*}{ Apr 7-8 } & 3 & 8.27 & 0.93 & 57 & 2.11 \\
\hline & 15 & 7.69 & 0.92 & 66 & 1.93 \\
\hline \multirow{2}{*}{ May 5} & 3 & 6.00 & 2.98 & 134 & 0.25 \\
\hline & 20 & 5.08 & 2.23 & 160 & 0.34 \\
\hline \multirow[t]{2}{*}{ May $19-20$} & 6 & 6.50 & 1.90 & 120 & 0.65 \\
\hline & 15 & 5.89 & 2.73 & 156 & 0.28 \\
\hline \multirow[t]{2}{*}{ Jul $7-8$} & 6 & 4.43 & 1.00 & 80 & 0.88 \\
\hline & 12 & 4.31 & 0.72 & 60 & 1.47 \\
\hline \multicolumn{6}{|c|}{$\begin{array}{l}1 \text { (RNA-N or DNA-N/Total N) } \times 100 \\
2([D N A / 0.0154] / \text { Total C }) \times 100 \\
{ }^{3} \text { Calculated using Equation }(1), \text { div } d^{-1}\end{array}$} \\
\hline
\end{tabular}

\section{DISCUSSION}

The results demonstrate that it is possible to measure RNA and DNA in natural samples easily. The DNA/C and RNA/DNA ratios found in the culture studies are quite sirnilar to those obtained using other less convenient and/or sensitive methods (Holm-Hansen et al., 1968; Holm-Hansen, 1969; Wallen and Geen, 1971; Healy and Hendzel, 1975; Rhee, 1978; Li, 1979; Michelson and Yentsch, 1979). The field data show

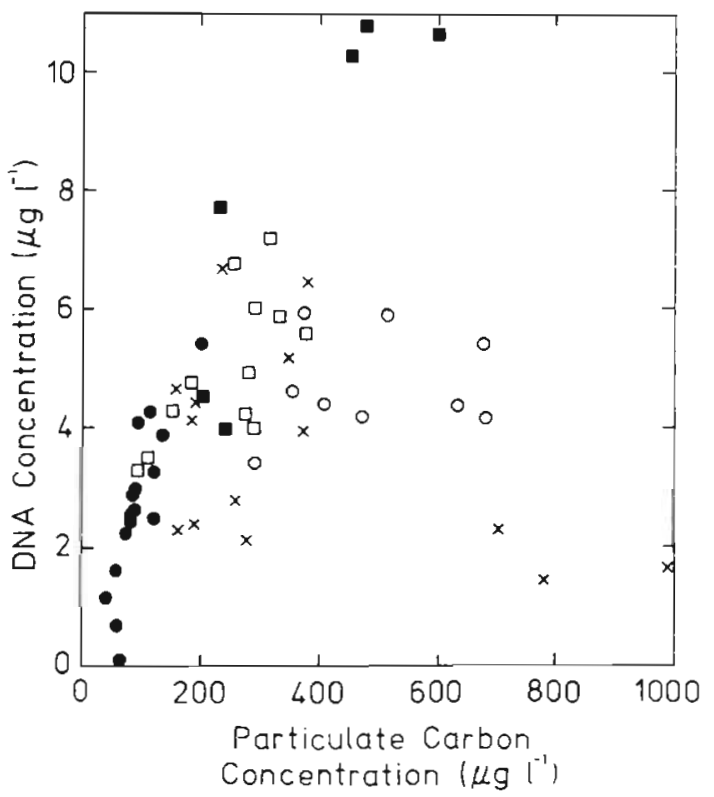

Fig. 7. DNA concentration as a function of total (particulate organic) carbon concentration in Dabob Bay: $\bullet$ Mar. 9-11; 0 April 7-8; - May 5; $\square$ May 19-20; x July 7-8

that there are indeed major changes in RNA and DNA concentrations and the RNA/DNA ratio with season and depth in the water column. Despite using a method which measures RNA by difference, the standard errors on samples taken over 12 to $36 \mathrm{~h}$ in the same place (Fig. 5), which includes analytical variation and variability due to sampling and patchiness, are quite low and comparable to that of the other more standard methods.

The DNA concentrations measured in Dabob Bay are somewhat lower than those obtained by Paul and Carlson (pers. comm.) for coastal areas, but similar to their data and the results of Holm-Hansen et al. (1968) for oceanic regions. This may result in part from the generally low productivity in Dabob Bay (Shuman, 1978), particularly in the surface layers in the summer, and in part because the DNA in organisms $<1 \mu \mathrm{m}$ in size was not measured.

Now that a suitable method is available for making RNA and DNA measurements, there are 2 critical questions which must be addressed: (1) Can DNA 
concentrations be used as a measure of living biomass? (2) Can RNA/DNA ratios be used as an indicator of growth rate?

\section{DNA as a measure of living biomass}

The major argument against the use of DNA as a measure of living biomass has been the possible occurrence of detrital DNA proposed by Holm-Hansen et al. (1968). They suspected that DNA was not rapidly degraded when organisms died because estimates of living carbon in a few natural samples, using the DNA/ $C$ ratio from their phytoplankton culture studies, were quite high. Similar results were obtained in this study as well. However, there are sufficient data presented here to show that when chlorophyll a concentrations are high in natural samples, DNA/C ratios from phytoplankton studies give more reasonable results for the percentage of total carbon that is living. This suggests that there may be some variation in the DNA/C ratios among different groups of organisms. DNA/C ratios are not generally available, but a few DNA/C dry weight ratios, which would be proportional to DNA/C ratios have been measured for diverse groups of organisms. While it is difficult to draw conclusions from such limited data, it appears that the DNA/dry wt ratio is somewhat lower for algae (Holm-Hansen, 1969; HolmHansen et al., 1968) and protozoas (Scherbaum et al., 1959; Friz, 1968) than for bacteria (Fuhrman and Azam, 1982; Paul and Carlson, pers. comm.), and zooplankton (Dagg and Littlepage, 1972; Båmstedt and Skjoldal, 1976; Skjoldal and Båmstedt, 1976). Paul and Carlson (pers. comm.) also examined their samples by epifluorescence microscopy when the DNA/C ratio was high in particulate matter smaller than $1 \mu \mathrm{m}$. They observed virtually no detrital particulate material which could contribute to the high DNA values, leading them to conclude that some bacteria have high DNA/C ratios. Further indirect evidence against the occurrence of detrital DNA is supplied by a recent study of phytoplankton growth rates measured by following changes in DNA concentrations during light and dark incubations (Falkowski and Owens, 1982). In calculating the growth rates, the best fit for the data was obtained by assuming no detrital DNA; if the concentration of detrital DNA was assumed to be greater (10 to $50 \%$ of the total DNA), the statistical correlation was not as good.

Besides the interest in DNA as a biomass indicator, it is also important to clarify whether detrital DNA, and also detrital RNA, occur for other reasons: (1) RNA DNA ratios will not be a meaningful measure of growth rate if a significant fraction of either is detrital. (2) DNA, and RNA, synthesis rates have been proposed as a measure of microbial productivity (e. g. Karl, 1981;
Moriarity and Pollard, 1981; Fuhrman and Azam, 1982) but specific rates cannot be calculated for natural populations if there are significant detrital DNA or RNA concentrations. The presence of large amounts of extra- and intra-cellular RNAses (El-Hamalawi et al., 1975), and the rapid turnover of RNA in cells, suggests it is not very likely to be present in non-living organic matter. The data and discussion presented here suggest that detrital DNA is not as much of a problem as originally hypothesized (Holm-Hansen et al., 1968), but more direct evidence is still required.

The possible variation in the DNA/C ratio between organisms will present a problem in converting DNA concentrations to living carbon. However, the range of variation may not be as great as, for example, with the ATP/C ratio (Banse, 1980 and references therein). Furthermore, DNA is a much more stable compound than ATP, the other commonly used indicator of living biomass, so that sampling and extraction of DNA does not present the problems incurred when measuring ATP concentrations. The problem of a variable DNAVC ratio may be most easily solved by size fractionation combined with DNA measurements, since the DNA/C ratio within groups, for example 12 phytoplankton species (Holm-Hansen, 1968; Holm-Hansen et al., 1969; data presented here) is quite constant. Even greater resolution can be obtained using a flow cytometer, which can measure the DNA content, as well as size and chlorophyll content of single cells, so that different groups within a size class can be distinguished (Yentsch et al., submitted). The critical information - the DNA/C ratio of organisms, such as large or attached bacteria, non-photosynthetic flagellates, ciliates, etc., which are all in the same size fraction as phytoplankton - is unknown and requires further study.

In Dabob Bay biomass distribution, as indicated by DNA, differed at times from that of chlorophyll $a$, particulate carbon and particulate nitrogen. For example, in the surface layer, the chlorophyll maximum occurred in early April, the DNA maximum in early May, and the particulate carbon concentrations reflected both maxima (Fig. 5). In other situations, DNA concentrations do not follow any of the other biomass measurements (e. g. Fig. 6, July 8). Since DNA measures non-phytoplankton, as well as phytoplankton biomass, DNA would not necessarily be correlated with chlorophyll a concentrations and since both detrital carbon and nitrogen exist, DNA may not be related to the total particulate carbon or nitrogen.

The percentage of the total (particulate organic) carbon which was calculated to be living was generally high (Table 1), although when chlorophyll concentrations were low, the high percentage of living carbon resulted from the use of an inappropriate DNA/C ratio. 
Even when the chlorophyll concentrations were high, so that the DNA/C ratios for phytoplankton were more appropriate, the percentage of the living fraction was never $<50 \%$ of the total carbon.

\section{RNA/DNA ratios as a measure of growth rate}

Even more important than using DNA as a measure of biomass may be the ability to estimate growth rates from RNA/DNA ratios. Very few data are available on

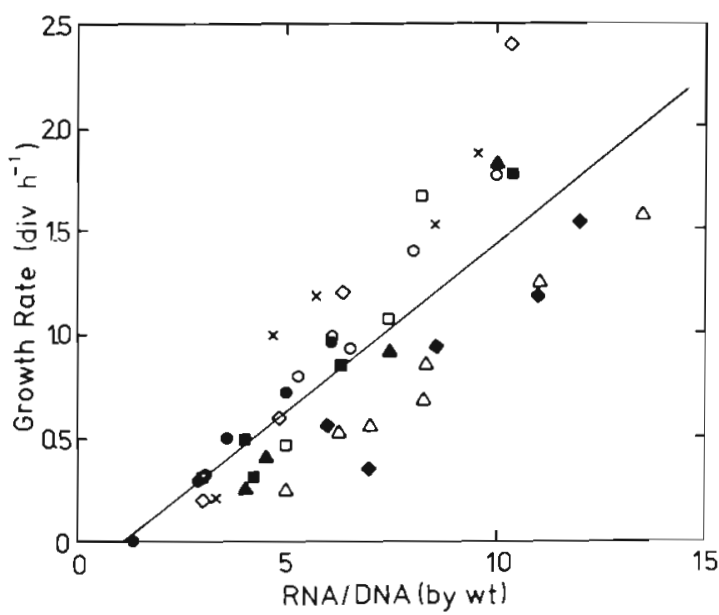

Fig. 8. Growth rate as a function of RNA/DNA ratio in nonmarine bacteria whose growth was limited by different combinations of suboptimal $\mathrm{N}$ and $\mathrm{C}$ sources; - Aerobacter aerogenes strain 5-P14 (Neidhard and Magasanik, 1960, Table 1); O Salmonella typhimurium strain 521D (Rosset et al., 1966, Table 2); Escherichi coli strain ML 30 (Rosset et al., 1966; Fig. 4); $\square$ E. coli strain ML308 (Rosset et al., 1966, Fig. 4); $\triangle$ E. coli strain B (Rosset et al., 1966, Fig. 4); $\triangle$ E. coli strain K12 520505 (Rosset et al., 1966, Fig. 4); o E. coli strain C600 (Rosset et al., 1966, Fig. 4); $\bullet$ Salmonella typhimurium wildtype (Kjeldgaard and Kurland, 1963, Table 1); x Aerobacter aerogenes strain LIII-1 (Rosset et al., 1966, Table 3). Line represents Equation (5)

the relationship between RNA/DNA ratios and growth rate for phytoplankton. In the present study, growth rate was linearly related to the RNA/DNA ratio and one equation could be used to describe 3 out of 4 cultures, all of whose growth was ultimately nitrogen limited. The equation (Eq. 2) for the 4th culture, which was not nitrogen limited, had the same slope, but a different intercept. In the only other experiments which may be comparable to those here, using freshwater phytoplankton grown in nutrient-limited (2 phosphate-limited and 1 nitrate-limited) chemostats (Healey and Hendzel, 1975; Rhee, 1978), the RNA DNA ratio was linearly related to growth rate for 2 out of 3 species, but for only 1 of these was the line describing the relationship similar to Eq. (1),

$\mu=0.376$ RNA/DNA $-0.640, \mathrm{r}^{2}=0.975, \mathrm{n}=5$
(Healey and Hendzel, 1975; Scenedesmus quad. ricauda, data taken from Fig. 5). However, the very different analytical procedures for measuring RNA and DNA and the use of chemostats at steady state, as opposed to batch cultures where both the growth rate and the RNA/DNA ratio are changing rapidly, may explain some of the differences between these studies.

There are even fewer data by which to determine the relationship between the growth rate and RNA/DNA ratios either within other groups of marine organisms, such as among marine bacteria, or between groups, such as phytoplankton and small zooplankton, whose size ranges overlap. In fact, even though RNA and DNA have been measured in zooplankton (Dagg and Littlepage, 1972; Båmstedt, 1976; Båmstedt and Skjoldal, 1980) no attempt has been made to relate the growth rate to RNA/DNA ratios. For marine macrozooplankton, the growth rate of a variety of organism can be linearly related to the RNA/dry wt ratio (Bamstedt and Skjoldal, 1980), suggesting that RNA/DNA ratios will also be related to growth rate. The only group of organisms for which the relationship between growth rate and RNA/DNA ratio has been extensively studied is non-marine bacteria, with growth conditions and growth rates quite unlike those in the ocean (Neidhardt and Magasanik, 1960; Kjeldgaard and Kurland, 1963; Rosset et al., 1966). Interestingly, if these data are plotted (Fig. 8), a linear relationship is obtained down to very low growth rates:

$\mu=0.156$ RNA/DNA $-0.141, \mathrm{r}^{2}=0.634, \mathrm{n}=45$

where $\mu=$ growth rate in $\operatorname{div} \mathrm{h}^{-1}$; RNA/DNA ratio on weight basis.

The available data show that in general the growth rate is linearly related to the RNA/DNA ratio. For estimating growth rates in the field from RNA/DNA ratios, it would be most simple if a single relationship can be used for all organisms. Within major groups such a relationship may hold, but between major groups there are not enough data for marine organisms, grown under typical conditions, to judge. Given the range of expected growth rates is large, the most general relationship may be found between $\mu / \mu_{\max }$ and the RNA/DNA ratio. However, measurements of RNA/ DNA after size fractionation may allow the determination of absolute growth rates in different groups of organisms, although of course, there is some overlap between the kinds of organisms in most size fractions. Finally, when growth rates are estimated from RNA/ DNA ratios measured for natural populations, even with size fractionation, it will be an average rate (as is ${ }^{14} \mathrm{C}$ uptake by natural phytoplankton populations), no matter how general the relationship between growth rate and RNA/DNA is for cultured, diverse marine organisms, because the range of growth rates in any 
one sample will probably be quite large. What is most important are the big difference in the ratio, which in this study appears to vary between $<1$ and approximately 20. Using the relationship of growth rate to RNA/DNA ratios for phytoplankton (Eq. 1), this range represents growth rates between 0 and $5 \mathrm{~d}^{-1}$ (from Eq. 1). Such large differences in the average rate growth obviously result from very different conditions. Furthermore, measurements of RNA/DNA ratios in individual cells with a flow cytometer (Yentsch et al., submitted) can give the growth rates in different organisms within the same size class.

Measurements of RNA/DNA are in some ways comparable to measurements of adenylate energy charge (EC), which is an indicator of physiological state (Karl and Holm-Hansen, 1978). The RNA/DNA ratio offers a number of advantages (1) ATP is a very labile compound which is rapidly converted to ADP or AMP as a result of brief stress or storage. Thus, the ATP content or EC of organisms can be radically altered during net tows, filtration, extraction or storage, even when great care is taken (e. g. Jones and Simon, 1977; Skjoldal and Båmstedt, 1977; Bulleid, 1978; Karl and HolmHansen, 1978; Perry et al., 1979; Karl and Craven, 1980). Although RNA is susceptible to degradation by cellular RNAses, short-term stresses, such as sampling, filtration, and extraction, do not appear to alter the RNA content. Storing samples in liquid $\mathrm{N}_{2}$ and precautions taken during analysis (Karsten and Wollenberger, 1977) prevent long term degradation. (2) Measuring EC by enzymatically converting AMP to ADP to ATP and then determining the ATP is a time consuming, complex process. Furthermore, the enzyme which converts AMP to ADP is not very efficient (Karl and Holm-Hansen, 1978; Christensen and Devol, 1980); thus, large amounts of AMP and large sample sizes may be required. In contrast, RNA and DNA can be rapidly and easily determined on a single, small sample. (3) The EC can vary only between 0 and 1 and is $>0.5$ in most living organisms. Thus, EC can only describe the physiological state very generally. The RNA/DNA ratio varies over a much wider range and the error associated with it is concomitantly quite small. As a consequence, the physiological state or growth rate can be defined as precisely as is appropriate for a mixed, natural population.

When average growth rates are calculated from the RNA/DNA ratios obtained in Dabob Bay using Eq (1), they are similar to other measured values of natural populations of phytoplankton in coastal areas (Goldman et al., 1979). A mean growth rate is difficult to interpret since it represents some bacteria and animals as well as phytoplankton. However, the highest average growth rates were always associated with chlorophyll maxima in this study. Low growth rates were found early in spring when light levels were low and in late spring and summer when nitrogen concentrations were low. High growth rates were found during the spring bloom and later in the chlorophyll maximum, associated with the nutricline. The very high average growth rates obtained in association with the summer chlorophyll maximum are particularly interesting since they are much higher than would be expected even for very fast growing phytoplankton. Perhaps there were also large bacterial numbers associated with the chlorophyll maximum, which raised the average growth rate. In this case, as in most others, size fractionation would have made it possible to examine the growth rates of different groups of organisms.

\section{CONCLUSIONS}

Considerable effort has been expended in the past in biological oceanography to determine the biomass and growth rate of planktonic organisms, with little consensus being reached about either (Eppley, 1981). By taking advantage of specific biochemical markers, such as RNA and DNA, it may be possible to do both. We have assessed the feasibility of utilizing DNA concentrations as a measure of living biomass and RNA/ DNA ratios as an indicator of growth rate, using a modification of the ethidium bromide method, which is very sensitive. Although some critical information is still lacking about the DNA/C ratio and the variation of the RNA/DNA ratio with growth rate for diverse marine organisms, these measures do have considerable potential application in oceanography.

Acknowledgements. This research was supported by NSF grants OCE 79-1959-1 and OCE 81-1793-7 awarded to Dr. S. I. Ahmed. Contribution no. 82033 of Bigelow Laboratory for Ocean Sciences and No. 1323 of School of Oceanography, University of Washington. We wish to thank Dr. M. J. Perry, Dr. W. G. Harrison, and Mr. B. Irwin for introducing us to measurements of RNA and DNA using the Prasad et al. (1972) method and Dr. David J. Carlson for critically reading this manuscript and allowing us to read an early draft of his manuscript on particulate DNA in seawater (Paul and Carlson, in prep.).

\section{LITERATURE CITED}

Båmstedt, U., Skjodal, H. R. (1976). Studies on the deep-water pelagic community of Korsfjorden, western Norway. Adenosine phosphates and nucleic acids in Euchaeta norvegica (Copepoda) in relation to its life cycle. Sarsia 60: $63-80$

Båmstedt, U., Skjoldal, H. R. (1980). RNA concentration of zooplankton: relationship with size and growth. Limnol. Oceanogr. 25: 304-316

Banse, K. (1980). Microzooplankton interference with ATP estimates of plankton biomass. J. Plankton Res. 2: 235-238

Brunschede, H., Dove, T. L., Bremer, H. (1977). Establishment 
of exponential growth after a nutritional shift-up in Escherichia coli $\mathrm{B} / \mathrm{r}$ : accumulation of deoxyribonucleic acid, ribonucleic acid, and protein. J. Bact. 129: 1020-1033

Buckley, L. J. (1979). Relationships between RNA-DNA ratio, prey density, and growth rate in Atlantic cod (Gadus morhua) larva. J. Fish. Res. Bd Can. 36: 1497-1502

Bulleid, N. C. (1978). An improved method for the extraction of adenosine triphosphate from marine sediment and seawater. Limnol. Oceanogr. 23: 174-178

Bulow, F. (1970). RNA/DNA ratios as indicators of recent growth rates of a fish. J. Fish. Res. Bd Can. 27: 2343-2349

Caldwell, P. C., Mackor, E. L., Hishelwood, C. (1950). The ribose nucleic acid content and cell growth of Bact. lactis aerogenes. J. chem. Soc. 1950: 351-3155

Christensen, J. P. (1974). An oxygen budget for the deep waters of Dabob Bay using respiration rates estimated from plankton electron transport activities. M. S. thesis, University of Washington, Seattle

Christensen, J. P., Devol, A. H. (1980). Adnosine triphosphate and adenylate energy charge in marine sediments. Mar. Biol. 56: 175-182

Dagg, J. J., Littlepage, J. L. (1972). Relationship betweeñ growth rate and RNA, DNA, protein, and dry weight in Artemia salina and Euchaeta elongata. Mar. Biol. 17: $162-170$

Davis, C. O. (1972). Lighting systems. In: Pavlou, S. P. (ed.) Phytoplankton growth dynamics, Technical Series I. Chemostat methodology and chemical analyses. Special Report No. 52, Department of Oceanography, University of Washington, Seattle, p. 19-23

Dennis, P. P., and Bremer, H. (1974). Macromolecular composition during steady-state growth of Escherichia cols Br. J. Bact. 119: 270-281

El-Hamalawi, A.-R. A., Thompson, J. S., Barker, G. R. (1975). The fluorometric determination of nucleic acids in pea seeds by use of ethidium bromide complexes. Analyt. Biochem. 67 : 384-391

Eppley, R. W. (1981). Relations between nutrient assimilation and growth in phytoplankton with a brief review of growth rate in the ocean. Can. Bull. Fish. Aquat. Sci. 210: $251-263$

Falkowski, P. G., Owens, T. G. (1982). A technique for estimating phytoplankton division rates by using a DNAbinding fluorescent dye. Limnol. Oceanogr. 27: 776-782

Friederich, G. E., Whitledge, T. E. (1972). In: Pavlou, S. P. (ed.) Phytoplankton growth dynamics, Technical Series I. Chemostat methodology and chemical analyses. Special Report No. 52, Department of Oceanography, University of Washington, Seattle, p. 38-55

Friz, C. T. (1968). The biochemical composition of the free -living amoebae Chaos chaos, Amoeba dubia, and Amoeba proteus. Comp. Biochem. Physiol. 26: 81-90

Fuhrman, J. A., Azam, F. (1982). Thymidine incorporation as a measure of heterotrophic bacterioplankton production in marine surface waters; evaluation and field results. Mar Biol. 66: 109-120

Goldman, J. C., McCarthy, J. J., Peavy, D. G. (1979). Growth rate influence on the chemical composition of phytoplankton in oceanic waters. Nature, Lond. 279: 210-215

Green, B. R. (1974). Nucleic acids and their metabolism. In: Stewart, W. D. P. (ed.) Algal physiology and biochemistry. University of California Press, Berkeley, p. 281-313

Guillard, R. R. L., Ryther, J. H. (1962). Studies of marine planktonic diatoms I. Cyclotella nana Hustedt and Detonula confervacea (Cleve) Gran. Can. J. Microbiol. 8: 229-239

Haines, T A. (1973). An evaluation of RNA/DNA ratio as a measure of long term growth in fish populations. J. Fish. Res. Bd Can. 30: 195-199

Healey, F. P., Hendzel, L. L. (1975). Effect of phosphorus deficiency on two algae growing in chemostats. J. Phycol. 11: 303-309

Holm-Hansen, O. (1969). Algae: amounts of DNA and organic carbon in single cells. Science, N. Y. 163: 87-88

Holm-Hansen, O., Sutcliffe, W. H., Jr., Sharp, J. (1968). Measurement of the deoxyribonucleic acid in the ocean and its ecological significance. Limnol. Oceanogr. 13: 507-514

Jeener, R. (1953). Ribonucleic acid and protein synthesis in continuous cultures of Polytomella caeca. Arch. Biochem. Biophys. 43: 381-388

Jeffrey, S. W., Humphrey, G. F. (1975). New spectrophotometric equations for determining chlorophylls $a, b, c_{1}$, and $c_{2}$ in higher plants, algae, and natural phytoplankton. Biochem. Physiol, Pflanzen 167: 191-194

Jones, J. G., Simon, B. M. (1977). Increased sensitivity in the measurements of ATP in freshwater samples with a comment on the adverse effect of membrane filtration. Freshwater Biol. 7: 253-260

Karl, D. M. (1981). Simuitaneous rates of ribonucieic acid and deoxyribonucleic acid syntheses for estimating growth and cell divison of aquatic microbial communities. Appl. environ. Microbiol. 42: 802-810

Karl, D. M., Craven, D. B. (1980). Effects of alkaline phosphatase activity on necleotide measurements in aquatic microbial communities. Appl, environ. Microbiol. 40: 549-561

Karl, D. M., Holm-Hansen, O. (1978). Methodology and measurement of adenylate energy ratios in environmental samples. Mar. Biol. 48: 185-197

Karsten, U., Wollenberger, A. (1977). Improvements in the ethidium bromide method for direct fluorometric estimation of DNA and RNA in cell and tissue homogenates. Analyt. Biochem. 77: 464-470

Kester, D. R., Duedall, I. W., Connors, D. N., Pytkowicz, R. M (1967). Preparation of artificial seawater. Limnol Oceanogr. 12: 176-179

Kjeldgaard, N. O., Kurland, C. G. (1963). The distribution of soluble and ribosomal RNA as a function of growth rate. $J$. molec. Biol. 6: 341-348

Laws, E. A., Archie, J. W. (1981). Appropriate use of regression analysis in marine biology. Mar. Biol. 65: 13-16

Leick, V. (1968). Ratios between DNA, RNA, and protein in different microorganisms as a function of maximal growth rate. Nature, Lond. 217: 1153-1155

Li, W. K. W. (1979). Cellular composition and physiological characteristics of the diatom Thalassiosira weissflogit adapted to cadmium stress. Mar. Biol. 55: 171-180

Mickelson, C., Yentsch, C. M. (1979). Toxicity and nucleic acid content of Gonyaulax excavata. In: Taylor, M. A., Seliger, H. H. (eds.) Toxic dinoflagellate blooms. ElsevierNorth Holland, Inc., New York, p. 131-134

Moriarity, D. J. W., Pollard, P. C. (1981). DNA synthesis as a measure of bacterial productivity in seagrass sediments. Mar. Ecol. Prog. Ser. 5: 151-156

Neidhardt, F. C., Magasanik, B. (1960). Studies on the role of ribonucleic acid in the growth of bacteria. Biochim. Biophys. Acta 42: 99-116

Pease, A. K. (1976). Studies of the relationship of RNA/DNA ratios and the rate of protein synthesis to growth in the oyster, Crassostrea virginica. Fisheries and Marine Service Technical Report No. 622. Department of the Environment, Research and Development Directorate, Canada

Perry, W. B., Boswell, J. T., Stanford, J. A. (1979). Critical problems with extraction of ATP for bioluminescence assay of plankton biomass. Hydrobiologia 65: 155-163 
Prasad, A. S., DuMouchelle, E., Knovich, D., Oberleas, D. (1972). A simple fluorometric method for the determination of RNA and DNA in tissues. J. Lab. clin. Med. 80: 598-602

Rhee, G.-Y (1978). Dual nutrient limitation. Limnol. Oceanogr. 23: 10-25

Ricker, W. E. (1973). Linear regressions in fishery research. J. Fish. Res. Bd Can. 30: 409-434

Rosset, R., Julien, J., Monier, R. (1966). Ribonucleic acid composition of bacteria as a function of growth rate. $\mathrm{J}$. molec. Biol. 18: 308-320

Scherbaum, O. H., Louderback, A. L., Jahn, T. L. (1959). DNA synthesis, phosphate content and growth in mass and volume in synchronously dividing cells. Expl Cell Res. 18: 150-166

Shuman, F. R. (1978). The fate of phytoplankton chlorophyll in the euphotic zone - Washington coastal waters. Ph. D. Dissertation, University of Washington, Seattle, WA

Skjoldal, H. R., Båmstedt, U. (1976). Studies on the deep water pelagic community of Korsfjorden, western Norway. Adenosine phosphates and nucleic acids in Meganyctiphases norvegica (Euphausiacea) in relation to life cycle. Sarsia 61: 1-14

Sutcliffe, W. H., Jr. (1965). Growth estimates from ribonucleic acid content in small organisms. Limnol. Oceanogr. 10S: R253-R258

Sutcliffe, W. H., Jr. (1969). Relationship between growth rate and ribonucleic acid concentration in some invertebrates. J. Fish. Res. Bd Can. 27: 606-609

Thoresen, S. S., Dortch, Q., Ahmed, S. I. (1982). Comparison of methods for extracting intracellular pools of inorganic nitrogen from marine phytoplankton. J. Plankton Res. 4: 695-704

Wallen, D. G., Geen, G. H. (1971). Light quality and concentration of proteins, RNA, DNA, and photosynthetic pigments in two species of marine plankton algae. Mar. Biol. 10: $44-51$

Yentsch, C. M., Horan, P. K., Muirhead, K., Chisholm, P., Dortch, Q., Haugen, E., Legendre, L., Murphy, L. S., Olson, R. J., Perry, M. J., Phinney, D., Pomponi, S. A., Spinrad, R. W., Wood, M., Yentsch, C. S., Zahauranec, B. J. (1982). Flow cytometry and cell sorting: a powerful technique with potential applications in aquatic sciences. Limnol. Oceanogr., submitted

Young, A. W., Buddemeier, R. W., Fairhall, A. W. (1969). A new 60-liter water sampler built from a beer keg. Limnol. Oceanogr. 14: 634-637

This paper was submitted to the editor; it was accepted for printing on March 14, 1983 